\title{
Some Accounts on Culture Conditions of Callus Tissues of Solanum laciniatum Ait. for Producing Solasodine
}

\author{
Noriyo Hosoda, Hitoshi Ito and Michihiko Yatazawa \\ Faculty of Agriculture, Nagoya University, Chikusa, Nagoya, Japan \\ Received March 7, 1979
}

\begin{abstract}
Production of solasodine in callus cultures of Solanum laciniatum Ait. was examined under several culture conditions. The steroidal alkaloid was produced more actively in rapidly proliferating callus tissues cultured on $\mathrm{PN}$ medium. The alkaloid concentration in the tissue was about $0.05 \%$ (dry weight basis) during the first 5 weeks' culture. The highest accumulation of the alkaloid per culture was obtained with 2,4-D concentration in the medium at $1 \sim 2 \mathrm{ppm}$. It is noteworthy that the alkaloid production was not inhibited by such high concentration of 2,4-D as up to $10 \mathrm{ppm}$ in the medium. Supplementation of kinetin slightly increased the alkaloid production.
\end{abstract}

Several species in a genus Solanum are known to produce an alkaloid solasodine in commercially exploitable amounts. ${ }^{1)}$ Solasodine is easily converted to progesterone, ${ }^{2 \text { ? }}$ therefore this alkaloid is used as an important starting material for synthesizing various kinds of steroidal hormones in the pharmaceutical industry. ${ }^{3)}$

Several attempts have been made to produce steroidal alkaloids by tissue cultures of Solanum species, ${ }^{4 \sim 9)}$ but, no fruitful result has been obtained with the tissue cultures including those of S. laciniatum. ${ }^{8,8,10\}}$

In the preceding paper $^{11)}$ we reported that callus culture of $S$. laciniatum Ait. produced several kinds of steroidal compounds including a new steroidal alkaloid containing solasodine. The callus culture also produced steroidal sapogenin diosgenin, even though the amount of diosgenin in the culture was very small when compared with that of solasodine.

This paper reports several culture conditions which affect the production of steroidal alkaloid in the callus culture of $S$. laciniatum Ait.

\section{MATERIALS AND METHODS}

Callus tissue and culture method. A callus tissue of Solanum laciniatum Ait. used in this research was the same as mentioned in the previous paper. ${ }^{11)}$ Five pieces of callus inocula each weighing about $0.5 \mathrm{~g}$ (fresh weight) were grown on $40 \mathrm{ml}$ of test agar medium in a $100 \mathrm{ml}$ Erlenmeyer flask for 4 weeks at $25^{\circ} \mathrm{C}$ in the dark after 3 weeks preincubation on PN medium ${ }^{12)}$ unless otherwise indicated. Five to twenty replicates were employed in each treatment. Harvested callus tissues were dried at $70^{\circ} \mathrm{C}$ for $48 \mathrm{hr}$ and weighed.

Determination of total steroidal alkaloid. The amount of total steroidal alkaloid was determined ${ }^{13)}$ as follows:

Extraction: One g of dried and powdered callus tissues was refluxed with $40 \mathrm{ml}$ of $95 \%$ ethanol for $30 \mathrm{~min}$. The extract was filtered. Callus residue was washed twice with $2 \mathrm{ml}$ of ethanol. The filtrate and washings were combined and distilled under reduced pressure to remove solvent. In case of agar medium, the remaining medium after harvest was crushed and extracted with acetone. The extract was acidified to pH 3.0 with acetic acid and concentrated to small volume. The concentrated extract was counterextracted by methylene chloride and the residual solution was evaporated to dryness.

Hydrolysis: The residue was hydrolyzed with $3 \mathrm{ml}$ of $1 \mathrm{~N} \mathrm{NaOH}$. The neutralized solution was again acidified with $2 \mathrm{ml}$ of concentrated acetic acid and then diluted to a definite volume.

Spectrophotometry: To each $3 \mathrm{ml}$ of thus prepared sample solution in a separatory funnel, $5 \mathrm{ml}$ of acetate buffer ( $\mathrm{pH} 4.7)$ and $1 \mathrm{ml}$ of methyl orange $(0.05 \%)$ were added. After shaking for $10 \mathrm{sec}, 5 \mathrm{ml}$ of chloroform was added, and shaken for $3 \mathrm{~min}$. The chloroform layer was taken out, dried with anhydrous $\mathrm{Na}_{2} \mathrm{SO}_{4}$, and absorbance of the chloroform solution was read with a spectrophotometer (Specta-20, Beckman-Toshiba Ltd.) at $420 \mathrm{~m} \mu$. The concentration of steroidal alkaloid was calculated from the absorbance by the use of standard curve made with authentic solasodine. Alkaloid formation in the callus tissues was expressed 
by total content per culture flask or by $\mathrm{mg}$ alkaloid per one $g$ of dry tissue.

\section{RESULTS AND DISCUSSION}

Time course of alkaloid accumulation in callus

\section{tissue}

Growth and alkaloid accumulation in the callus tissue were measured over 10 weeks, incubation period as shown in Fig. 1. The growth curve (Fig. 1A) included three phases: induction, logarithmic and stationary phases, just like other callus tissues.

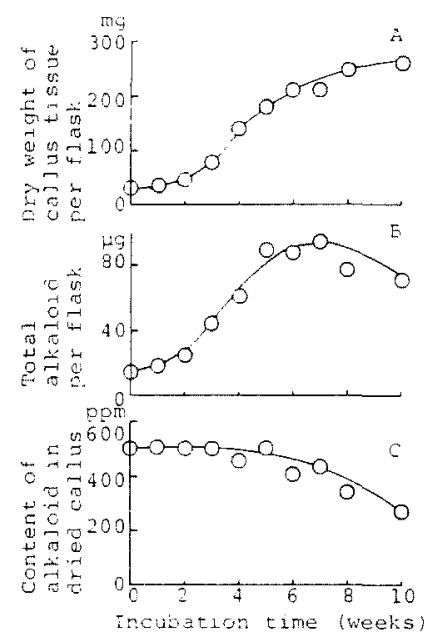

FIG. 1. Time Course of Growth and Solasodine Accumulation in Solanum laciniatum Callus Tissues. Callus tissues were cultured on PN media at $25^{\circ} \mathrm{C}$ in the dark. Dry weight and alkaloid content were measured at one week interval over 10 weeks' incubation period. The values in the figure were the mean of 5 to 20 replicate cultures.

Total amount of the alkaloid per culture increased rather rapidly in the early stage of incubation as compared with the growth of the callus tissues and the former attained to a peak after 7 weeks' incubation (Fig. 1B). After the peak, the total content of alkaloid per culture decreased gradually. The decrease would be resulted from the decomposition of the steroidal alkaloid, because the excresion of the alkaloid into the medium was not detected as described later.

The alkaloid concentration in the tissue was relatively high at an early stage of incubation and gradually decreased after 3 weeks (Fig. 1C). This may suggest that vigorously proliferating tissues have higher activity in synthesizing alkaloid than older one.

After harvesting callus tissues, culture medium was examined for steroidal alkaloid, because tobacco callus tissue was reported to excrete considerable amount of nicotine into the culture medium. ${ }^{14)}$ No case of more than ten examinations after $5 \sim 10$ weeks' culture period gave any indication of alkaloid excresion into the medium.

\section{Temperature}

Callus tissues were incubated at five different temperatures, $12,20,25,30$, and $37^{\circ} \mathrm{C}$, for 4 weeks (Fig. 2). Growth (Fig. 2A) was the highest at $25^{\circ} \mathrm{C}$. Very little and practically nil growth was observed under incubation temperature of 12 and $37^{\circ} \mathrm{C}$, respectively. At the latter temperature the callus tissue became

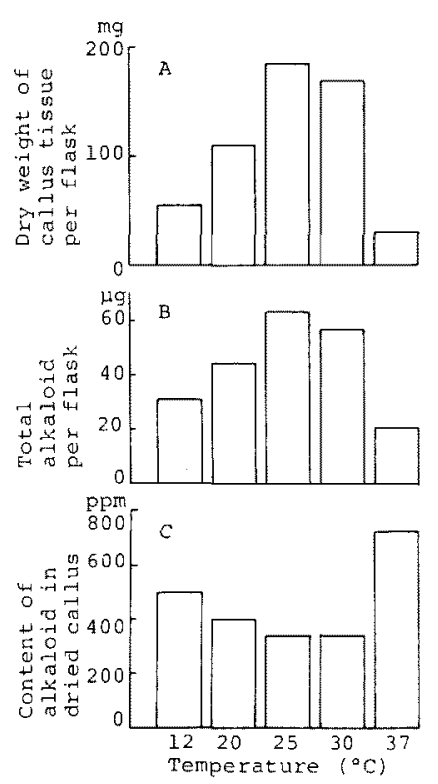

FIG. 2. Effect of Incubation Temperature on Growth and Solasodine Accumulation in Solanum laciniatum Callus Tissues.

Callus tissues were cultured on PN media at five different temperatures, $12,20,25,30$ and $37^{\circ} \mathrm{C}$ for 4 weeks. Values in the figure are the mean of 9 to 10 replicate cultures. 
slightly necrotic.

The amount of total alkaloid per fiask (Fig. 2B) was the highest with the culture incubated at $25^{\circ} \mathrm{C}$ followed by the culture at $30^{\circ} \mathrm{C}$. When the amount was expressed by the alkaloid concentration in callus tissue, the highest value was obtained at $37^{\circ} \mathrm{C}$ (Fig, 2C).

\section{2,4-D concentration}

Callus tissues were cultured for 4 weeks with a medium containing different concentrations of 2,4-D. Examined levels of 2,4-D were 0, $0.01,0.1,0.5,1,2$, and $10 \mathrm{ppm}$.

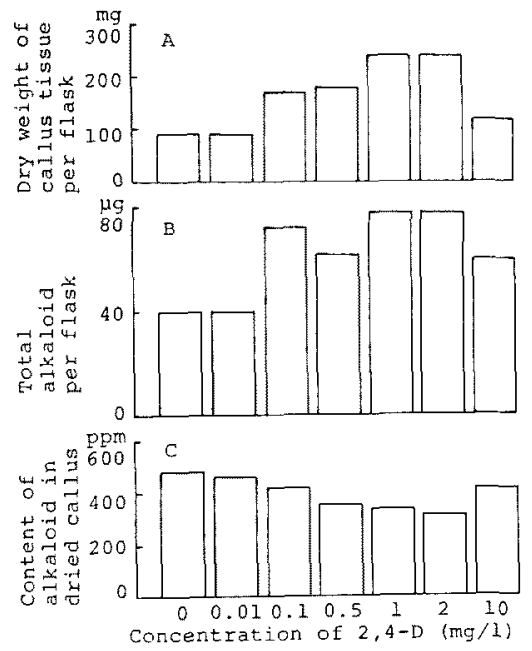

FIG. 3. Effect of 2,4-D Concentration in the Medium on Growth and Solasodine Accumulation in Solanum laciniatum Callus Tissues.

Callus tissues were incubated for 4 weeks on PN media containing varied concentrations of 2,4-D. Values in the figure are the mean of 10 to 12 replicate cultures.

Growth and alkaloid content of the harvested tissues are shown in Fig. 3. The growth of callus tissues was the most favorable with a medium containing 2,4-D at $1 \sim 2$ ppm (Fig.3A).

The highest value in total alkaloid per flask was also obtained with a medium containing 2,4-D at $1 \sim 2 \mathrm{ppm}$ (Fig. 3B). Even at $10 \mathrm{ppm}$ of 2,4-D, the production of alkaloid didn't decrease very much. These levels of 2,4-D in the medium are extraordinarily high for producing the alkaloid by plant tissue cultures.
It was shown with tobacco callus tissues, for example, that nicotine production was strongly reduced and nearly became nil when the culture medium contained 2,4-D at or over 1 ppm..$^{15,16)}$

The present results revealing that the alkaloid production was never inhibited but rather stimulated at above 2 ppm 2,4-D may create a new concept on the working mechanism of 2,4-D toward the biosynthesis of secondary metabolites with special reference to alkaloids.

\section{Other auxins and cytokinin}

The effect of NAA, IAA or kinetin supplementation to the medium on growth and alkaloid production of the callus tissue was examined. NAA or IAA was added to the culture medium at $1 \mathrm{ppm}$ concentration in place of 2,4-D. The effect of kinitin was examined by supplementing kinetin at $0.1 \mathrm{ppm}$ level to PN medium.

TABle I. EFFect of Auxins and Cytokinin ON Growth and Solasodine ACCUMULATION IN Solanum laciniatum CALlus Trssues

Callus tissues were cultured for 4 weeks on media supplemented with 2,4-D, NAA, IAA or 2,4-D plus kinetin. Values in the table are the mean of 7 to 10 replicate cultures.

\begin{tabular}{lccc}
$\begin{array}{c}\text { Plant } \\
\text { hormones } \\
\text { (Concentration) }\end{array}$ & $\begin{array}{c}\text { Dry } \\
\text { weight of } \\
\text { callus tissue } \\
\text { per flask } \\
(\mathrm{mg})\end{array}$ & $\begin{array}{c}\text { Total } \\
\text { alkaloid } \\
\text { per } \\
\text { flask } \\
(\mu \mathrm{g})\end{array}$ & $\begin{array}{c}\text { Content } \\
\text { of alkaloid } \\
\text { in dried } \\
\text { callus } \\
(\mathrm{ppm})\end{array}$ \\
\hline 2,4-D $1 \mathrm{mg} / \mathrm{liter}$ & 157 & 79 & 505 \\
NAA $1 \mathrm{mg} /$ liter & 119 & 64 & 540 \\
IAA $1 \mathrm{mg} /$ liter & 90 & 49 & 546 \\
2,4-D 1 mg/liter & & & \\
kinetin 0.1 mg/liter & 144 & 82 & 570 \\
\hline
\end{tabular}

The results are shown in Table I. The growth of callus tissues on media containing $1 \mathrm{ppm}$ of NAA or IAA was about two third of that obtained with PN medium. With NAA or IAA medium, early growth of callus tissues was retarded intensively and nearly no growth was observed over the first 2 weeks. Kinetin supplementation did not give any definite favorable effect on callus growth.

The amount of total alkaloid produced per flask was nearly parallel with the growth of 
callus tissues per flask, but the concentration of alkaloid in the tissues cultured with NAA or IAA seemed to be higher than that in the tissues cultured with 2,4-D. This figure was more clear in callus tissues grown on a medium supplemented with kinetin. Heble et al. ${ }^{7}$ reported that callus tissues of Solanum xanthocarpum did not produce solasodine on a medium containing IAA or NAA at $2 \mathrm{ppm}$. The present results clearly inconsistent with their observations, although the concentration of IAA or NAA employed was a little different.

\section{Origin of callus tissue}

Metabolic nature of callus tissues from the same plant species often deviates greatly each other. ${ }^{16)}$ This is also true with various strains of callus tissues originated from the same plant individual. The deviation would come from the mother cells from which the callus tissue was induced.

Therefore alkaloid production by callus tissues originated from root or hypocotyl cells of the same seedling and subcultured through 2 passages was examined.

Results showed that there was no difference in the growth and alkaloid production (root callus $351 \mu \mathrm{g} / \mathrm{g}$. D.W., hypocotyl callus 350 $\mu \mathrm{g} / \mathrm{g}$. D.W.) between these callus strains. Alkaloid producing activity of these juvenile callus tissues was nearly the same as that (330 $500 \mu \mathrm{g} / \mathrm{g}$. D.W.) of callus tissues which have been subcultured through more than 60 generations.

As a conclusion, callus tissues of Solanum laciniatum Ait. were shown to produce reasonable amount of solasodine alkaloid. The concentration of the alkaloid in cultured tissue was about $0.05 \%$ on dry weight basis up to 5 weeks of culture period. This value exceeds the concentration $(0.03 \%)$ of solasodine in roots of the mother plant even though other parts of the mother plants contain much. ${ }^{17,18}$ ) It is noteworthy that the production of solasodine alkaloid in callus tissues was not so much reduced by supplementing 2,4-D to the culture medium up to $10 \mathrm{ppm}$ which is generally accepted to be severely inhibitory for producing alkaloids with other callus tissues. ${ }^{15,18)}$ Further enhancement of the alkaloid production by revising culture conditions and selecting more active callus strains are now under research.

Acknowledgment. This research was partly supported by a grant from the Ministry of Education (Japan). The authors wish to acknowledge Dr. Y. Miyazaki, Izu Experiment Station of Medicinal Plants, National Institute of Hygienic Sciences, for his kind supplying the seeds of Solanum laciniatum Ait. and Solanum aviculare Forst., and Dr. M. Tabata, Kyoto University, for his kind suggestions.

\section{REFERENCES}

1) K. R. Khanna and A. S. Murty, Planta Med., 21, 182 (1972).

2) Y. Sato, H. G. Latham Jr. and E. Mosettig, J. Org. Chem., 22, 1496 (1957).

3) K. Schreiber, "The Alkaloids," Vol. X, ed. by R. H. F. Manske, Academic Press, New York, London, 1968, pp. 1 192 .

4) M. R. Heble, S. Narayanaswami and M.S. Chadha, Naturwiss., 55, 350 (1968).

5) M. R. Heble, S. Narayanaswami and M.S. Chadha, Science, 161, 1145 (1968).

6) D. Vágújfalvi, M. Maróti and P. Tétényi, Phytochemistry, 10, 1389 (1971).

7) M. R. Heble, S. Narayanaswami and M.S. Chadha, ibid., 10, 2393 (1971).

8) J. H. Supniewska and B. Dohnal, Diss. Pharm. Pharmacol., 24, 193 (1972), [C.A., 77, 58820 (1972)].

9) P. G. Kadkade and T. R. Madrid, Naturwiss., 64, 147 (1977).

10) P. Khanna and S. K. Manot, Indian J. Exptl. Biolog., 14, 631 (1976).

11) N. Hosoda and M. Yatazawa, Agric. Biol. Chem., 43, 821 (1979).

12) T. Murashige and F. Skoog, Physiol. Plant., 15, 473 (1962).

13) J. Birner, J. Pharm. Sci., 58, 258 (1969).

14) S. Ohta, O. Matsui and M. Yatazawa, Agric. Biol. Chem., 42, 1245 (1978).

15) T. Furuya, H. Kojima and K. Syono, Phytochemistry, 10, 1529 (1971).

16) I. Shiio and S. Ohta, Agric. Biol. Chem., 37, 1857 (1973).

17) B. Waclaw-Rozkrutowa, Diss. Pharm. Pharmacol., 18, 595 (1966), [C.A., 67, 29848 (1968)].

18) N. M. Ismailov and S. M. Aslanov, Dokl. Akad. Nauk. Azerb. SSR, 23, 47 (1967), [C.A., 67, 61606 (1968)]. 